\title{
Drama social e narrativas do assassinato de Aline
}

- Ana Letícia DE Fiori

Universidade de São Paulo, São Paulo, Sáo Paulo, Brasil

DOI: 10.11606/issn.2316-9133.v22i22p275-288

resumo Este artigo examina o "caso Aline", assassinato de repercussão nacional ocorrido em Ouro Preto/MG, em outubro de 2001, à luz da noçấo de drama social de Victor Turner, indicando como emergem arenas narrativas nas quais versões se confrontam e acionam certos paradigmas, tropos e valores. Discuto como narrativas fazem o caso transcender a lógica racional do campo jurídico configurando diferentes disputas acerca de noçôes como juventude; ficçâo e realidade; influências demoníacas na produção de uma cultura do terror. Examino o desfecho do drama social do "caso Aline" a partir das tensōes que provoca nas narrativas canônicas de produçấo de justiça e da aparente aporia que o caso gera com seu veredicto absolutório. Argumento que o próprio caráter fragmentado, lacunar e não acabado do encontro e confronto de narrativas no Tribunal do Júri, a despeito da lógica do controverso do Direito Penal, pode ter consigo possibilidades de justiça ao "caso Aline".

palavras-chave Narrativas jurídicas; Drama social; RPG; Arenas narrativas; Cultura do terror

\section{Social drama and narratives on the murder of Aline}

abstract This article examines the "Aline case", a national impact murder which occurred in Ouro Preto/MG, in October 2001. The case is approached as a Victor Turner's social drama, highlighting how narrative arenas arise, confronting versions on the case that engages several paradigms, tropes and values. I discuss how narratives makes the case transcends the rational logic of the juridical field, configuring different struggles around notions of youth, fiction and reality, demonic influence, creating a culture of terror. The finale of "Aline case" social drama is examined by the tensions it causes on the canonic narratives of justice making and the aporia it apparently generates in face of a non-guilty verdict. I suggest that the fragmented, lacunary and open-ended character of the meeting and confrontation of narratives in the Court Room, despite its logic of controversial, might carry on possibilities of justice to "Aline case".

keywords Juridical narratives; Social drama; RPG; Narrative arenas; Culture of terror

\section{Introduçáo}

Contando histórias de morte. Contando. Esse gerúndio nos coloca em espaços narrativos nos quais histórias de morte se produzem e nos produzem. Histórias. Múltiplas narrativas que se friccionam, ecoando os ruídos que estremecem a ilusão de se poder determinar como as coisas realmente aconteceram. De morte. Histórias feitas de morte, histórias que falam a morte, histórias que podem matar.

Abranger as múltiplas facetas de um caso de assassinato de grande repercussão exigiu uma abordagem de suas narrativas que não as tomasse como unidades de análise discretas, mas que as apreendesse em suas diferentes emergências, 
contextos de enunciação, recorrências e interpenetrações. Narrativas conformadas na polifonia que caracterizou a experiência social do "caso Aline" dentro e fora dos limites formais das instituições jurídicas. Tais narrativas foram reconstituídas a partir do inquérito e do processo criminal do caso; de notícias da mídia impressa, eletrônica e televisiva; de outros instrumentos jurídicos subsequentes ao caso; de entrevistas com participantes do "caso Aline" e da etnografia do julgamento.

A pesquisa foi delimitada inicialmente por um recorte cronológico, que se inicia com o assassinato de Aline em Ouro Preto/MG, em outubro de 2001 e, se encerra com a absolvição pelo Tribunal do Júri de quatro réus em julho de 2009, também em Ouro Preto. Considerando que os acontecimentos do "caso Aline" e suas narrativas se desenrolam em temporalidades regidas por diferentes intensidades, o recorte da pesquisa não concebe um tempo cronológico vazio e homogêneo. Analisa-se uma sequência de eventos cuja estrutura temporal possui uma qualidade dramática, que permite compreendê-la como uma unidade processual de forte carga simbólica e estética, um drama social nos termos de Victor Turner $(1973,1982)$. O recorte temporal, portanto, não configura a totalidade do que pode por ventura se referir ao "caso Aline"; mas ao ser desdobrado nas fases do drama social - ruptura, crise, ação reparadora e desfecho - fornece elementos para compreender os sentidos do "caso Aline" para seus diferentes participantes, a partir de alguns temas fundamentais, como justiça, impunidade, moralidade, fronteiras entre ficção e realidade, etc.

Este artigo examina o "caso Aline" enfeixado nas quatro fases de um drama social, indicando como emergem as arenas narrativas nas quais versóes sobre o caso se confrontam e acionam certos paradigmas, tropos e valores. Em seguida, discuto modos de abordar o campo jurídico por meio de narrativas. O desfecho do drama social do "caso Aline" é então examinado a partir das tensóes que provoca nas narrativas canônicas de produção de justiça e da aparente aporia que o caso gera com seu desfecho absolutório. Por fim, argumento que o próprio caráter fragmentado, lacunar e não acabado do encontro e confronto de narrativas no Tribunal do Júri, a despeito da lógica do controverso que visa opor diametralmente acusação e defesa diante da autoridade hermenêutica do juiz e do Conselho de Sentença, pode ter consigo possibilidades de justiça ao "caso Aline".

\section{Drama Social}

Ruptura. O espaço narrativo aberto pela morte da jovem Aline Silveira Soares, em 14 de outubro de 2001, espraia-se pelo pasmo inicial, pela transgressão de uma ordem presumida diante do ininteligível. O presente da ruptura é uma manhá de domingo, primeiro dia do horário de verão, já se encaminhando para o final da tradicional Festa do Doze, organizada pelos estudantes das repúblicas de Ouro Preto e frequentada por jovens vindos de muitas partes. Por uns dias, as ruas e os casaróes barrocos da cidade foram tomados por festejos profanos, contrastando com uma paisagem urbana marcadamente católica. O zelador do cemitério da Igreja Nossa Senhora das Mercês e Misericórdias (Mercês de Cima) - segundo seus diferentes depoimentos na delegacia, para os jornalistas e no fórum - dirige-se pela manhã ao cemitério. Ele teme encontrar rastros de vandalismo que se repetia diante dos usos não correspondentes à circunscrição sacra a que fora destinado o local. A praça em frente ao cemitério servira de acampamento para hippies e jovens que, entre suas tumbas e covas, frequentemente consumiam bebidas alcoólicas e drogas ilícitas e praticavam 
sexo. Alguns dias antes do assassinato, lápides haviam sido quebradas. Naquela manhã, o zelador encontra algo além do habitual nesses dias de festejos: um pequeno corpo com os braços abertos caído ao lado dos túmulos, tingido de sangue, que secara formando padrôes. À primeira vista, pareceram indícios de que a igreja fora invadida, Jesus Cristo fora arrancado do altar e lançado ao chão. O zelador se aproximou do corpo em posição de cruz e percebe tratar-se de uma jovem garota, nua e brutalmente assassinada. Não é uma escultura de Cristo na cruz, é seu inverso.

A cena do corpo de Aline no cemitério se coloca nos interstícios entre o presente aparentemente estático de um crime consumado e o passado ativo de sua execução. $\mathrm{O}$ que aconteceu? A cena é tão insólita que sucessivas leituras - realizadas posteriormente por investigadores, jornalistas, operadores do direito, moradores da cidade, etc. - mantêm parte da narrativa inicialmente aventada pelo zelador. Tal narrativa, tendo como cenário um cemitério profanado, no qual uma moça foi sacrificada em crucificação, emancipa-se do zelador e passa a circular, reproduzir-se e repetir-se em outros sujeitos, materializando outros enunciados, repletos de meandros, variâncias e reavaliaçóes. Em outros espaços e com outros enunciadores, a narrativa produz seus próprios efeitos.

Crise. A morte da jovem estudante capixaba, que visitava a festa estudantil com a prima e uma amiga, ultrapassa os limites de uma convivência já carregada de tensôes entre moradores e estudantes de Ouro Preto. Traços perigosos de um modo de vida estudantil, náo alinhado com a economia moral majoritária da cidade, são elencados em relação causal com o crime por investigadores, jornalistas e pela população estarrecida: uso de drogas e bebidas; sexo; festas todos os dias; hospedagem irregular nas repúblicas cujos prédios são patrimônio da
Universidade Federal de Ouro Preto, mas que regidas livremente pela população flutuante de estudantes. Por sua vez, os estudantes de Ouro Preto buscam rebater as acusaçóes locais, evitar sua identificação como causadores de violências e as normatizações que adviriam dessa culpa. É preciso diferenciar-se do crime e do sujeito criminoso. Os acusados não poderiam ser, portanto, apenas estudantes.

Esses esforços de produção da diferença, em que o assassino é um outro e o assassinato rompe as expectativas de um crime ordinário, fazem emergir novos elementos, símbolos florescendo em narrativas que começam a enfatizar obsessivamente o caráter misterioso do assassinato. A cada recontar do caso, congela-se a cena do crime no quadro de um ritual macabro, perpetrado por seres sinistros que existem na fronteira transgredida entre ficção e realidade. Teias de realismo fantástico (TAUSSIG, 1987) são fiadas quando o demônio e seus representantes entram na cena do crime. As páginas do inquérito policial e as manchetes dos cadernos policiais dos jornais ${ }^{2}$ introduzem os protagonistas do "caso Aline": três estudantes suspeitos de serem o Anjo da Morte, o Vampiro e o Corvo (im)possíveis personagens de um jogo de interpretação de papeis ${ }^{3}$ (RPG) que, ao ganharem vida, teriam conduzido Aline à morte. Esta trama fantástica, cujos fios midiáticos e investigativos buscam se assemelhar aos jogos de RPG sem com eles construir de fato um diálogo intertextual, estabelece a participação da amiga e da prima de Aline, que teriam violado os laços de amizade e de parentesco na barbaridade do crime. Este estranho jogo, chamado RPG, é tornado o sexto suspeito do crime e, posteriormente, o quinto réu do processo. ${ }^{4}$

A ruptura da ordem social e simbólica de Ouro Preto provocada pela morte de Aline precipitou-se na crise que cresceu para se tornar o drama social (TURNER, 1973, 1982) do "caso 
Aline". Um drama social pode ser compreendido a partir das fases de ação pública que formam as unidades do processo. Principia-se com uma ruptura das relaçóes formais, regidas pela norma. Diante da ruptura, há a crise crescente, que alarga a ruptura e gera clivagens, posicionando participantes em relaçóes de oposição. A terceira fase é a ação reparadora, na qual são operacionalizados mecanismos de ajuste e regeneração, geralmente por membros representativos da estrutura, e se desenvolve uma réplica à crítica dos eventos que compuseram a crise.

Crise. Ação reparadora. Para quem? De modo relacional e contrastivo, em um contínuo jogo de mimese e alteridade (TAUSSIG, 1993), os participantes e enunciadores do caso tentam definir papéis e posiçóes de si e dos outros, construindo-lhes em imagens que permitem ter poder sobre esses outros de acordo com os diferentes regimes de verdade operados nos boatos da cidade, nos veículos de comunicação, no processo judicial e nos púlpitos dos templos.

Como nos cânones do romance policial, ecoa a pergunta: Quem matou Aline? Descreve-se exaustivamente a cena do crime, o corpo em posição de cruz, obliterando uma narrativa da dinâmica do crime que precisasse as ações de assassino(s) e vítima. Flutuam as versóes, o número de golpes, os possíveis atos de assassino(s) e vítima, a despeito dos peritos determinarem em seu laudo que Aline recebeu 17 facadas em uma rota de fuga pelo cemitério, até ser morta por esgorjamento.

Contudo, os grandes investimentos narrativos acerca da autoria do crime não se concentram nas açóes que os acusados teriam ou não praticado para assassinar Aline, e sim na possibilidade do assassinato ter como fonte motivadora o transbordamento da ficção dos jogos de RPG para a realidade, com a realização de um ritual satânico. O crime, o ritual e os jogos são assemelhados para que se estabeleça a plausibi- lidade e fiabilidade dessa acusação. As lacunas e incertezas quanto aos eventos da noite de 14 de outubro de 2001 permitem a multiplicação de versōes coexistentes.

Assim, consolida-se uma narrativa dominante a partir do léxico: jogo, ritual, sexo, drogas, jovens estudantes, vampiro, facadas, cemitério, crucificação, além de qualificativos como macabro, brutal, satânico, bárbaro, horrendo. Um longo esforço de demonização da pessoa dos acusados, da cena do crime, da própria violência da morte de Aline e de um tipo de jogo apontado como veículo para esta morte. Nas reportagens exibidas pela Rede Globo 5 imagens da monstruosidade exercida na morte de Aline são seguidas de ilustraçôes de monstros fantásticos de jogos de RPG, enquanto se narra o desenrolar do processo. Ao mesmo tempo em que acessam um imaginário pressuposto, plantam-no e o florescem nos espectadores, a partir das lacunas de informaçóes que os espectadores são provocados a preencher.

Conforme as narrativas se confrontam, intercambiam-se os papéis de vítima e de algoz, bem como as acusaçóes de mistificação e a identificação de vulnerabilidades. Assim, a mãe de Aline e sua família são ditas vítimas dos assassinos de Aline e da lentidão da justiça, que parece escapar na dilatação do tempo do processo, apesar dos esforços da promotora, que assume o caso em 2004, de realizar o julgamento. Os acusados se dizem vítimas de uma produção de justiça ineficaz e das ondas persecutórias - que se estenderão aos jogadores de RPG, conforme os conflitos se escalonam para esferas, para além do processo do "caso Aline” - originadas, segundo eles, pelo preconceito dos investigadores e do sensacionalismo da imprensa. A juventude é considerada vítima potencial de um jogo capaz de enlouquecer ou arregimentar almas, pessoas ou consciências subliminarmente para as forças demoníacas. 
Drama Social e narrativas do assassinato de Aline 279

Aline assume um papel ambivalente ao ser representada nas narrativas. É a jovem incauta que se meteu com as pessoas erradas, na hora errada. Ela enredou-se na trama macabra de sua própria morte ao participar da festa; ao jogar RPG; ao confiar na prima; ao viajar sem dinheiro e hospedar-se na casa de desconhecidos. Cada um desses "passos em falso" de Aline é negado pelos depoimentos de seus familiares, que responsabilizam a prima de Aline. A prima, entre os quatro acusados, é a que atrai mais atenção nas narrativas do processo judicial e da imprensa, nas quais ganha atributos suspeitos como cabelos vermelhos, hábitos noturnos, depressão e rebeldia. Conforme depoimentos de testemunhas e reportagens da imprensa, alargam cada vez mais o contraste entre Aline e os acusados. A inocência, generosidade e virtude de Aline são ressaltadas quase a um status de santidade, como em uma foto publicada no jornal Estado de Minas em 19 de maio de 2005, na qual Aline está envolta em uma aura de luz e exibe asas de anjo. Ao contrário da imagem santificada de Aline, seu corpo é silenciado, na medida em que os laudos dos peritos se tornam menos relevantes e pistas como exames de digitais e DNA deixam de ser produzidas, ou se perdem nos trâmites do processo.

Desfecho. A última fase de um drama social (TURNER, 1973, 1982) é a reintegração ou cisma, clímax, solução ou resultado temporário. Esta também é a fase em que o observador faz um balanço do processo analisando o continuum sincronicamente, podendo comparar o antes e o depois. O clímax do "caso Aline" é o julgamento dos quatro réus (por não ser uma pessoa física, os jogos de RPG não são acusados criminalmente do ponto de vista procedimental, mas nas oitivas e debates são também avaliados, submetidos a juízos morais e indicados como agentes dos acontecimentos), e as expectativas se voltam para a condenação e punição destes.
Após cinco dias de julgamento, o Conselho de Sentença vota que os réus não concorreram para a prática do crime e o veredito provoca um novo estarrecimento, pois a falta de condenação indica um crime sem solução, equalizando absolvição, impunidade e injustiça. Contudo, dramas sociais também tem um papel central em precipitar a percepção de contradição em comportamentos, o que leva à aceitaçáo de novas narrativas (BRUNER, 1986, p. 153).

\section{Arenas narrativas}

Nas fases de crise e ação reparadora de um drama social pode haver uma "escalada", com a disputa alcançando outras instâncias e formando arenas concretas nas quais os participantes do drama social buscam afirmar seus próprios paradigmas a partir de conflitos. As disputas no "caso Aline" ultrapassam a apuração dos fatos da sua morte, na medida em que atores e narrativas transitam nessas diferentes arenas, assumindo características específicas de enunciação e confronto. No "caso Aline", posicionam-se acusados, estudantes de Ouro Preto, jogadores de RPG em constante comunicação pela internet, operadores do direito direta ou indiretamente envolvidos no processo, legisladores, pastores evangélicos, a família de Aline, o padre da Igreja Mercês de Cima. A imprensa assume o papel de meio, de mediador e de ator diretamente engajado no desenrolar dos eventos.

A arena basilar para o caso Aline é a constelação de procedimentos, de peças processuais, de instituiçôes, de atores, de códigos jurídicos, de instrumentos e de investigaçóes, na qual as narrativas foram produzidas para compor o inquérito e o processo criminal ${ }^{6}$. Conforme a fase da crise se acentua, há um deslocamento do investimento investigativo. 
Investigadores, em tese, buscariam identificar sujeitos e determinar as suas condutas que produziram o resultado morte (tipificado no artigo 121 do Código Penal brasileiro). Contudo, não é esta a narrativa do crime que se busca ao se questionar "quem matou Aline?", uma vez que não é da explicação racionalizante exigida pelo Código de Processo Penal que emerge a matriz de inteligibilidade do crime. Enredando-se mais e mais na produção de uma cultura do terror que relaciona o assassinato e os acusados a seitas satânicas e jogos de RPG, o drama social do "caso Aline" adquire forma a partir das metáforas e paradigmas nas mentes de seus atores que, "em determinadas circunstâncias intensivas, geram formas sem precedentes que legam à História novas metáforas e paradigmas" (TURNER, 1973, p. 11).

Os jogos de RPG, seu fluxo entre ficção e realidade e sua apropriação liminóide (TURNER, 1982) de elementos culturais das mais diversas fontes para a construção da narrativa coletiva tornaram-se um signo especialmente flexível para a construção da "realidade" do crime como extraordinário e grotesco (TAUSSIG, 1987 , p. 113-116). O "caso Aline" aflorava, portanto, um repertório de violências afinado com as tendências de reencantamento do mal, produzindo até mesmo suas encenaçôes, como as páginas do Estado de Minas ${ }^{7}$ que mimetizam um livro de RPG para noticiar casos reais de assassinato. Os jogos de RPG se prestam, nesses termos, à germinação de uma cultura do terror que se espraiou por diferentes esferas, no escalonamento de conflitos do drama social do "caso Aline", por meio da obscuridade epistemológica que dá

contornos e voz à forma informe da realidade, na qual uma atuação recíproca de verdade e da ilusão torna-se uma força social fantasmagórica. Todas as sociedades vivem através de ficções to- madas como algo real. O que distingue as culturas do terror é que o problema epistemológico e ontológico da representação, além de outros problemas filosóficos - a realidade e a ilusão, a certeza e a dúvida -, torna-se algo infinitamente maior do que um "mero" problema filosófico de epistemologia, hermenêutica e desconstrução. Torna-se um meio de dominação altamente revestido de poder (TAUSSIG, 1987, p. 126-127).

O escalonamento dos conflitos abre, para além do processo criminal, arenas narrativas midiática, mágico-religiosa e jurídico-política - , nas quais as histórias de morte que se contam estão em constante confrontação. A elaboração de motivaçóes subjetivas dos suspeitos assume o primeiro plano nas disputas, e estes passam a ser suporte de esforços de caracterização da criminalidade, da loucura e da satanização a partir das quais o caso é compreendido. Suas próprias versões da história são enredadas na trama dominante, encontrando dificuldade em serem recebidas como versões legítimas e plausíveis, à medida que suspeitos se tornam cada vez mais acusados, um papel negativado para além do abusivo uso midiático do termo "supostos" para modalizar suas próprias acusações. Ao se tornarem dominantes, as versóes narrativas em que Aline fora crucificada por jogadores de RPG que realizaram um ritual satânico (versóes cuja veracidade foi afinal o cerne da disputa no "caso Aline") prescrevem a condenação dos acusados como ação reparadora e desfecho do drama. Contudo, tais versões demandam também formas de combater diferentes focos de ameaça que ocasionaram o crime, em outras instâncias.

O "caso Aline" e o RPG atraem a atenção de atores religiosos, estabelecendo ali outra arena narrativa. Diferentes atores do campo evangélico pentecostal brasileiro encontraram nos jogos de RPG uma materialização do mal cotidiano, 
Drama social e narrativas do assassinato de Aline $\mid 28$ I

cujo domínio e enfrentamento são constitutivos de suas práticas. $\mathrm{Na}$ forma contemporânea de sua "Teologia da Guerra Espiritual”, pregam que o demônio é um ser que age nesse mundo, revela-se de várias maneiras e é responsável pela vida errada daqueles sob sua influência que, muitas vezes, o veneram sem o saber. Nesse enquadramento, jovens que jogam RPG são ao mesmo tempo enganados e malfeitores. Assim como os relatos de conversão pentecostal costumam enfatizar menos o arrependimento do que a libertação (MARIZ, 1997, p. 50-56), o "caso Aline" tornou-se parte e mola propulsora de uma agenda pentecostal que se espraiou para as arenas jurídico-política e midiática, nas quais os jovens são objeto de intervenção para libertação. Nas redes sociais, RPGistas relataram frequentemente que seus familiares ouviram "pastores" advertindo contra o jogo. Surgiram publicações de editoras evangélicas explicitamente atribuindo os jogos de RPG às forças do mal, retratando os jogos como formas de corrupção dos jovens. Em uma história em quadrinhos publicada na Revista Cristã (edição 11, pp. 74-76), um garotinho agride um cachorro sob instruçóes de seu "mestre do RPG", mas é convencido pelas outras crianças a fazer o bem ao seguir o verdadeiro mestre: Jesus.

$\mathrm{Na}$ arena jurídico-politica, jogos de RPG ganham a atenção de um procurador do Ministério Público Federal e de vereadores e deputados de base evangélica. Considerando o período entre 2001 e 2009, foi possível levantar uma Ação Civil Pública (ACP) do Ministério Público Federal; seis leis ou projetos de lei em âmbito municipal e estadual que buscaram restringir ou proibir a venda de jogos de RPG, ou mesmo proibir a prática do jogo; e uma portaria do Ministério da Justiça normatizando o consumo de materiais de RPG por meio de classificação indicativa etária. ${ }^{8} \mathrm{~A}$ maior parte dos projetos de lei, apresentados em âm- bito municipal ou estadual, é recusada por ser considerada inconstitucional, uma vez que esta seria competência da União.?

Jogadores de RPG articulam contranarrativas que buscam minar as certezas da narrativa dominante. Em 2002, é fundada a ONG Ludus Culturalis, que promoveu uma série de atividades de divulgação do RPG, com especial ênfase em suas potencialidades pedagógicas, dentro e fora do contexto escolar. A Ludus promoveu quatro ediçôes do Simpósio RPG e Educação (em 2002, 2003, 2004 e 2006) que congregou pesquisadores acadêmicos e professores de diferentes campos disciplinares unidos pela temática dos RPGs. Proliferam nos anos 2000 pesquisas acadêmicas em diferentes níveis e campos disciplinares sobre os jogos de RPG, principalmente aquelas realizadas por psicólogos e educadores; muitos também jogadores. Produzir um discurso acadêmico sobre jogos e jogadores de RPG poderia ser também uma forma de buscar um reconhecimento capaz de sobrepujar formas estigmatizantes e criar um espaço de enunciação legítimo para esse "nós jogadores de RPG”, bem como para propiciar defesas diante das acusaçóes que proliferaram diante do "caso Aline".

\section{Desfechos e aberturas}

Os quatro acusados pelo assassinato de Aline são denunciados e têm a prisão decretada em dezembro de 2004. Por meio da atuação de seus advogados, conseguem, contudo, aguardar o julgamento em liberdade a maior parte do tempo. A prima de Aline, porém, permanece presa por quase dez meses, em 2005 . O peso das acusaçóes interfere diretamente na vida dos quatro réus. Os três estudantes da Universidade Federal de Ouro Preto abandonam ou transferem seus cursos para outras cidades, vivendo à som- 
bra de uma possível nova prisão. Ao longo dos anos seguintes, outros crimes são relacionados aos RPGs ou a seitas satânicas e espetacularizados pela imprensa brasileira, reeditando acusaçóes e trazendo seus nomes e rostos de volta ao público. Conforme definição de seus advogados de defesa, os acusados sofrem um prolongado "linchamento moral", equiparado ao caso da Escola Base e outros em que a imprensa promoveu condenaçãa e punição sumárias, de modo parajudiciário. $\mathrm{O}$ julgamento pelo Tribunal do Júri do "caso Aline", após sucessivos adiamentos, enfim acontece entre os dias 01 e 05 de julho de 2009. Ouro Preto torna-se, novamente, o palco central do drama social do "caso Aline" para a sua fase derradeira.

Percebendo que "reparação e prevenção são objetivos evocados, direta ou indiretamente, pelos oradores do Júri” (SCHRITZMEYER, 2002, p. 123), cabe-nos refletir a respeito dos ruídos e tensôes que permanecem não-resolvidos e não-reparados mesmo com a conclusão do caso e a absolvição dos réus.

Diante do acúmulo de conflitos do drama social, os réus se encaminharam para o julgamento no lugar do que René Girard denomina bodes emissários, ou seja, vítimas com as quais a sociedade poderia estabelecer uma relação de alteridade e assim direcionar a violência, a fim de impedir a explosão dos conflitos (GIRARD, 1972). Girard afirma que sociedades como a nossa prescindem de ritos sacrificiais na medida em que o sistema judiciário racionaliza a vingança, assumindo seu monopólio. $\mathrm{O}$ judiciário dissimula aquilo que o identifica com a vingança ao mesmo tempo em que revela sua semelhança, impedindo, contudo que sua vingança seja vingada. Diante de um caso de grande repercussáo como o "caso Aline", a expectativa de vingança havia sido amplamente disseminada e catalisada por um cânone discursivo de impunidade diante dos entraves da Justiça no Brasil.
Os réus, como bodes emissários no clímax do drama social, podiam incorporar a tensão presente em Ouro Preto entre "estudantes" e "moradores", mas sem a solidariedade dos estudantes das Repúblicas Federais, que se mantém há décadas e são ocupadas por alunos de cursos mais tradicionais e valorizados, como engenharia e direito. A prima da vítima era, por sua vez, a dobradiça das rusgas entre suas famílias materna e paterna (a qual Aline pertencia). Assim como a narrativa do crime se recobre de realismo fantástico, por meio da incerteza ante ao horizonte da verossimilhança que abarca as explicaçóes do crime (TAUSSIG, 1987, PINA CABRAL, 2003), a vida dos personagens é fabulada e traduzida em lenda de homens infames, em que não se decide entre o verdadeiro e o falso. Apesar de toda a exploração de nomes e imagens dos acusados, conta-se muito pouco sobre eles, cuja existência é reconhecida apenas pelas acusações que sofrem. A descrição do terror da morte de Aline opera em "uma íntima dependência mútua entre a verdade e a ilusão, e entre o mito e a realidade" (TAUSSIG, 1987, p. 87).

Em seu ensaio "O Saber Local", Clifford Geertz propóe abordar os sistemas jurídicos como formas distintas de imaginar a realidade. Às instituiçôes jurídicas cabe traduzir a linguagem da imaginação para uma linguagem de decisão, formando um senso de justiça. $\mathrm{O}$ processo jurídico é, desse modo,

uma forma de conseguir que nossas concepçóes do mundo e nossos veredictos se ratifiquem mutuamente, ou, utilizando uma expressão menos cotidiana, fazer com que essas concepçóes e esses veredictos sejam respectivamente o lado abstrato e o lado prático da mesma razão constitutiva (GEERTZ, 1983, p. 181).

Porém, nas arenas narrativas do "caso Aline”, e especialmente no Tribunal do Júri, o 
Drama social e narrativas do assassinato de Aline 283

esforço do contraditório em produzir e eleger uma narrativa única equivalente à realidade do crime se fissurava em brechas de equívoco, possibilidade e obscuridade, criando uma imaginação social do caso na qual as pessoas poderiam manter opinióes alternativas simultaneamente, tornando nômades os papéis de culpado, vítima, testemunha, investigador, juiz.

\section{Os sentidos da absolviçáo}

O "caso Aline" colocou em evidência uma série de comportamentos que determinados agentes queriam "denunciar", tornando o julgamento dos réus e seu veredicto um instrumento tanto para guarnecer iniciativas legislativas restritivas (os projetos de proibição dos jogos de RPG ou, no âmbito mais restrito da cidade de Ouro Preto, as tentativas de regular a atividade das repúblicas estudantis e da Festa do Doze) quanto de oficializar a reprobabilidade desses comportamentos (e daqueles que os praticam).

Colocando em relevância o papel da vítima nesse processo entendemos também o poder enunciativo concedido à mãe de Aline, especialmente pela cobertura midiática, que a apresentava por vezes como a principal vítima do assassinato de Aline. E é no papel de vítima que o jornal Estado de Minas dá espaço para os réus do "caso Aline", após sua absolvição, representando "o preço da suspeita" que eles tiveram que pagar durante os oito anos do caso. Como vítimas de um poder estatal que os teria violentado ao tentar resolver a violência da morte de Aline, é aberta a possibilidade dos réus tornarem-se também acusadores. Assim, os advogados de defesa aventam a possibilidade de processar o Estado por danos morais.

A tentativa do sistema Judiciário (e da aliança entre Judiciário e Mídia) de racionali- zar vingança como justiça faz com que ambos os termos surjam em diferentes discursos e narrativas do "caso Aline", ora como equivalentes, ora como necessariamente distintos. A matriz narrativa dominante para o processo penal é orientada pelo que Álvaro Pires denomina de "racionalidade penal moderna",

um sistema de pensamento ligado a um conjunto de práticas institucionais jurídicas que se designa como 'justiça penal' ou 'criminal", constituído por uma rede de sentidos com unidade própria no plano do saber e que liga estreitamente fatos e valores, o que lhe confere um aspecto normativo (PIRES, 2004, p. 38).

Pires afirma que a racionalidade penal moderna fundamenta a punição como uma obrigação ou necessidade, deslocando o sentido da faculdade de punir para a obrigação de punir, uma obrigação ao mesmo tempo pragmática, política e moral. A ideia de direito penal como última instância, ultima ratio, deixa de significar a decisão de punir ou não o crime para significar a seleçáo daquilo que cabe punir (PIRES, 2004). Um corolário dessa concepção, dessa identidade entre crime e pena e de punição como obrigação, é que um crime não punido parece sugerir que o bem violado foi menosprezado, acessando a ideia de impunidade e de falha da justiça.

Ao se reduzir a noção de justiça à necessidade de uma pena aflitiva, na lógica de que "o mal se sana pelo mal” (PIRES, 2004, p. 47), o cânone narrativo sobre criminalidade e justiça estabelece apenas dois desfechos possíveis: a punição e a impunidade. A 'justiça' praticada pelo Júri obscurece suas desigualdades intrínsecas, para que seja aceita e legitimada por seus participantes, criando a ilusão teatral de que promove, em nome de algo superior, uma luta maniqueísta entre 'bem' e 'mal', certo e errado, 
perdão e punição, compreensão e vingança" (SCHRITZMEYER, 2002, p. 119-120). O desfecho absolutório, embora previsto pelo sistema jurídico, encontra-se assim aparentemente em uma aporia. A princípio, é visto como impunidade, injustiça e como o não reconhecimento da vítima e do seu direito violado. Mas talvez, a percepção fragmentária que se constrói do caso, indicando a falta de uma totalidade que se possa produzir pelas narrativas, abre possibilidade de outra ordem, uma retomada do passado em uma relação de não-identidade consigo mesmo que é também uma abertura sobre o futuro, um inacabamento constitutivo.

Narrar os eventos de um crime é a princípio organizá-los temporária e limitadamente em uma elaboração tensa, regrada e linear, suspendendo-os da realidade confusa. A partir desta organização, acusação e defesa desenvolvem argumentos e provas, os quais culminam numa sentença, também aparentemente perfeita, acabada e coerente (SCHRITMEYER, 2002, p. 35). Trata-se de uma montagem social de narrativas "tanto das formas, que restam 'filtradas' e registradas nos processos, quanto das informais, que se pode acompanhar em audiências" que "orienta-se bastante para a sacralização do monopólio do sistema de justiça estatal enquanto legítimo regulador de comportamentos" (SCHRITMEYER, 2002, p. 117).

Diante de certas experiências vividas pelos indivíduos, que seriam inenarráveis e intoleráveis, como experiências tidas como violentas, os esquemas repetidos a cada sessão do Júri orientam percepçôes e atitudes individuais dos participantes, permitindo-lhes "objetivar estados subjetivos, formular impressóes informuláveis e integrar experiências inarticuladas" (LÉVI-STRAUSS, 1949, apud SCHRITZMEYER, 2002, p. 45). Estes casos levados a julgamento revigoram a experiência do próprio Júri, atribuindo-lhe sentido. Contudo, esta tendência de reconciliação e totalização traz o risco de suprimir ruídos que, no "caso Aline", eram por demais ensurdecedores.

$\mathrm{O}$ que pode significar esta sentença absolutória, após um esforço tão intenso e assimétrico de satanização dos elementos acusados? Se no Tribunal do Júri "é irrelevante a descoberta de se o acusado matou ou não a vítima, pois o que importa é por que ele é acusado de tê-la matado" (SCHRITZMEYER, 2002, p. 76), pode-se levantar a hipótese de que a lógica da divisão nós e outros, construída a partir da exibição de traços opostos de caráter sobre um eixo "cidadãos que se tornam vítimas" e "criminosos", tropeçou em seus próprios excessos e ambiguidades, na fricção do encontro de narrativas proporcionada pelo julgamento. $\mathrm{O}$ julgamento tornou-se um encontro de narrativas no qual os narradores se contradizem mutuamente, e cada opinião contradiz a si mesma em um excesso de imagens ambíguas. Imagens como a da posiçấo do corpo de Aline ou a dos personagens vampirescos dos jogos de RPG, arranjadas em uma montagem de fragmentos e elementos de possibilidade, que colidem uns com os outros, com seus fantasmas de vários contornos e disfarces, aproximando-se sorrateiramente um do outro no espaço de suas diferenças (TAUSSIG, 1987, p. 102).

Do mesmo modo que a morte de Aline náo foi negada ou legitimada, a absolvição dos réus tampouco legitimou sua morte social, promovida por anos de inscrição em suas imagens e seus nomes da autoria dos assassinatos e da barbárie ali subjacente. Seus corpos, portanto, foram tornados objeto de uma economia de poder que buscou inscrever uma mitologia para a dominação (idem, p. 45-48). Narrando as vidas dos réus desde o crime, posto que seu tempo de vida é reconstruído e reelaborado "a partir da constatação de se houve ou não repetição de comportamentos social e legalmente recrimináveis" (SCHRITZMEYER, 2002, p. 
Drama social e narrativas do assassinato de Aline 285

103), a defesa evidenciou o peso que as acusações lhes trouxeram, o quanto lhes foi impossível defender-se até o julgamento.

Talvez convencido pela defesa, coube ao Conselho de Sentença, face ao princípio do in dúbio pro réu e agenciando o conceito de ultima ratio para a autolimitação do poder punitivo estatal, encerrar o movimento de produção de vítimas sacrificais no âmbito judicial, ainda que o linchamento moral não pudesse ser de todo represado. O Júri, afinal, não é entendido apenas como um lugar de sujeição, por envolver poder e arenas de luta, mas um ritual lúdico e agonístico, que "permite a construção de subjetividades e a redefinição de experiências sociais" (SCHRITMEYER, 2002, p. 08). Encerrado o julgamento, julgados os recursos e arquivado o processo, o "caso Aline" restou como uma trama aberta, cujos fios narrativos permanecem soltos.

O não acabamento do "caso Aline" teria também efeitos de despertar? As perguntas que restaram, o choque da sentença com as narrativas hiperbólicas reiteradamente apresentadas, não poderiam ser também uma forma de "estilhaçar o imaginário da ordem natural, através da qual, em nome do real, o poder exerce sua dominação"? É possível por suas fissuras entender o ser social dos regimes de verdade do caso Aline, entender a política de sua interpretação e representaçáo? É possível mobilizar o terror das narrativas do "caso Aline" a fim de subverter seus modos de representação da violência, fazendo com que o poder se enrede sem sua própria desordem? (TAUSSIG, 1987, p. 15)

Creio que o julgamento do "caso Aline" se mostrou um inusitado ritual de cura ante o espaço de representação do criminoso e da violência. Estes significantes, capazes de engendrar regimes de verdade e processos de subjetivação, escalonaram os conflitos para além da morte de Aline. Porém, é no espaço da morte de Aline que a montagem social de narrativas, a partir de seu encontro sísmico na lógica jurídica do contraditório, criou "uma espécie de espaço lúdico e de um espaço para testes, a fim de que se possa comparar as alucinaçóes com o campo social do qual elas emanam. Então o próprio espaço de representação é esquadrinhado" (TAUSSIG, 1987 , p.412). Esta montagem operou por alterações, brechas, deslocamentos e guinadas. Evocou quadros oscilantes em um espaço discursivo polifônico que conectaram e romperam conexôes entre dessemelhantes, rompendo com as principais tentativas de ordenamento narrativo e sensacionalismo, em uma "desordem ordenada" pelo ritual. Traçando um paralelo com as considerações de Taussig sobre o xamanismo, percebi nas diferenças criadas pelo encontro de narrativas uma atuação recíproca de alteridade que junta o ser e o imaginar em uma miscelânea de discursos que se alternam. "É um momento privilegiado no arranjo da realidade do mundo, no seu fazer e desfazer. Aqui está o poder" (TAUSSIG, 1987, p.428).

No começo da conferência sobre direito e justiça publicada em $A$ Força da Lei, Jacques Derrida chama atenção para a dupla acepção de "justo", que pode ter o sentido de justeza, adequação; ou o sentido jurídico-ético-político de justiça. Creio que uma narrativa justa do "caso Aline" é aquela em que, benjaminianamente (apud TAUSSIG, 1987), a verdade não seja uma questão da exposição que destrói o segredo, mas de revelação que lhe faz justiça, a partir de uma forma justa e adequada de narrar, capaz de preservar seus ruídos.

\section{Notas}

1. Este artigo examina narrativas reunidas ao longo da pesquisa de mestrado que deu origem à dissertação "Contando Histórias de Morte: etnografia do Júri e arenas narrativas do 'caso Aline"” (FIORI, 2012). Trata-se de uma versão revisada da comunicação apresen- 
tada no GT 58 "Sensibilidades jurídicas y sentidos de justicia en la contemporaneidad: interlocución entre Antropología y Derecho" da X Reunião de Antropologia do Mercosul, realizada em Córdoba, Argentina, em julho de 2013 e no GT 01 "Antropologia e Sistemas de Justiça Criminal" do III Encontro Nacional de Antropologia do Direito, realizado na Universidade de São Paulo, em agosto de 2013. A abordagem aqui desenvolvida é consonante com os esforços teóricos do Núcleo de Antropologia do Direito da Universidade de São Paulo - NADIR/USP, a partir de sua linha de pesquisa "antropologia da jurisprudência e de narrativas de violência”, em fundamentar uma abordagem antropológica para a relação entre narrativa, performance, experiência, violência e o campo jurídico. Pensar a dinâmica ritual e estética de um fenômeno jurídico remete também à inserção da pesquisa no projeto temático do Núcleo de Antropologia da Performance e Drama - NAPEDRA/USP, "Antropologia da Performance: drama, estética e ritual”, financiado pela FAPESP entre 2008 e 2013. Agradeço a Fabiana de Andrade pelos comentários para esta versão.

2. O corpus analisado no mestrado é constituído de cerca de 200 notícias de diferentes veículos, incluindo os jornais O Tempo e O Estado de Minas, o telejornal Jornal da Globo e portais da internet. A lista completa de notícias está em Fiori (2012).

3. Para minha análise dos jogos de interpretação de papéis (RPGs), ver a introdução de Fiori (2012). Para outras perspectivas sobre as polêmicas em torno dos jogos de RPG, ver Vasques (2008) e Fairchild (2007).

4. A outra amiga de Aline, provavelmente por ser menor de idade na data do crime, não foi acusada na peça de denúncia produzida pelo Ministério Público em dezembro de 2004.

5. Por exemplo, a matéria "Ao que tudo indica", exibida pelo Jornal da Globo em 20/12/2004. O texto da matéria está disponível em: <http://g1.globo.com/ jornaldaglobo/0,,MUL894508-16021,00-AO+QUE +TUDO+INDICA.html>. As matérias sobre o "caso Aline” exibidas pela Rede Globo até o começo do julgamento eram praticamente idênticas.

6. O número original do processo criminal do "caso Aline" é TJMG 046101002833-4, posteriormente recebendo a numeração única: 0028334-51.2001.8.13.0461. Pelo número do processo, foi possível acompanhar sua tramitação no site do Tribunal de Justiça de Minas Gerais. Posteriormente, obtive uma cópia do processo emprestada pelos advogados de defesa.
7. Refiro-me ao especial "Terras Satânicas”, assinado por Fernanda Odilla et al. na edição de 29/05/2005 do Estado de Minas (Belo Horizonte/MG, p. 21-23).

8. Ação Civil Pública no . 39623-21.2001.4.01.3800, de autoria de Fernando de Almeida Martins; Lei Ordinária de Vila Velha-ES, no 3909/2002; Projeto de Lei RJ 2516/2005, de autoria de Fábio da Silva; Projeto de Lei DF 1947/2005, de autoria de Agrício Braga; Projeto de Lei ES 136/2005, de autoria de Robson Vaillant; Projeto de Lei ES 137/2005 e Lei Ordinária de Guarapari-ES No 2506/2005, ambas de autoria de Reginaldo de Almeida. Ministério da Justiça; Portaria $\mathrm{n}^{\circ} 1.100$, de 14 de julho de 2006.

9. Em 2006, o website da ONG Ludus Culturalis publica dois artigos questionando o PL DF 1947/2005. O advogado Marcelo Alexandre Leite assina "A inconstitucionalidade do Projeto de Lei no 1.947/2005 do Distrito Federal”. O artigo, após uma breve contextualização, começa por discutir a competência legislativa do projeto. Cita uma parte da Constituição (art. 21) que atribui à União a competência pela classificação de "diversôes públicas". No parágrafo 3o. do artigo 220, consta que compete à lei federal a classificação etária das diversôes públicas. Para enquadrar o RPG juridicamente como diversão pública, o artigo evoca a portaria 1.100/2006, que atribui ao Ministério da Justiça a classificação indicativa das diversões públicas “jogos eletrônicos e de interpretação (RPG)" (Art.3o. inciso II). Maria do Carmo Zanini, editora de livros de RPG, assina "Por que o PL 1947/2005 do DF está equivocado: não há fundamentação", questionando a atribuição de violência aos jogos, a confusão entre RPGs e jogos eletrônicos e a noção de que os jogos viciariam.

10. O IV Simpósio RPG e Educação: educação, entretenimento ou violência? (no qual eu apresentei a pesquisa de iniciação científica "A Construção da Identidade RPGista”), realizado em setembro de 2006, destinou-se especialmente a enfrentar as controvérsias em torno do RPG e casos de assassinato no Brasil, que ganharam novo fôlego após o assassinato de uma família em Guarapari/ES, cujos autores alegaram participar de uma partida de RPG. Os casos de Guarapari e Ouro Preto costumam ser equiparados nas narrativas midiáticas e ao longo do processo do "caso Aline", embora seus desfechos sejam bastante distintos. Até onde pude verificar, os dois acusados de Guarapari foram institucionalizados em um manicômio judiciário. 
Drama social e NarRativas do asSassinato de Aline $\mid 287$

\section{Referências bibliográficas}

BRUNER, Edward M. Experience and its Expressions e Ethnography as Narrative. In: TURNER, Victor W; BRUNER, Edward M (orgs.). The Anthropology of Experience. Chicago: University of Illinois Press, 1986.

BRUNER, Jerome. Acts of Meaning. Cambridge, MA: Harvard University Press, 1990.

"A Interpretação Narrativa da Realidade". In: $A$ Cultura da Educação. Porto Alegre: Artmed, 2001.

Making Stories. Law, literature, life. New York: Farrar, Straus and Giroux, 2002.

DAWSEY, John. Cowart. Victor Turner e antropologia da experiência. In: Cadernos de Campo (USP), São Paulo, v. 13, p. 163-176, 2005.

Turner, Benjamin e antropologia da performance: o lugar olhado - e ouvido - das coisas. In: Campos (UFPR), v. 7, p. 17-25, 2006.

Por uma antropologia benjaminiana: repensando paradigmas do teatro dramático. In: Mana (UFRJ. Impresso), v. 15, p. 349-376, 2009.

FAIRCHILD, Thomas Massao. Leitura de impressos de RPG no Brasil: o satânico e o secular. Tese (Doutorado). Curso de Educação, USP, São Paulo, 2007.

FIORI, Ana Letícia de. Contando histórias de morte: etnografia do júri e arenas narrativas do "caso Aline". Dissertação (Mestrado em Antropologia Social) Faculdade de Filosofia, Letras e Ciências Humanas, Universidade de São Paulo, São Paulo, 2012.

FOUCAULT, Michel. Arqueologia do saber. Rio de Janeiro: Forense, $7^{\text {a }}$ ed., 2008.

Vigiar e Punir: nascimento da prisão. Petrópolis: Vozes, 31 a ed., 2006.

A vida dos homens infames. In: Estratégia, poder-saber. Ditos e escritos $I V$. Rio de Janeiro: Forense Universitária, 2003.

GEERTZ, Clifford. Local Knowledge: Fact and Law in Comparative Perspective. In: Local Knowledge - Further Essays in Interpretative Anthropology. New York: Basic Books, 1983, p. 167-234.

GINZBURG, Carlo. Feitiçaria e piedade popular: Notas sobre um processo modenense de 1519; Sinais - Raízes de um Paradigma Indiciário. In: Mitos, Emblemas e Sinais. São Paulo: Cia das Letras, 1989.

História Noturna - decifrando o Sabá. São Paulo:
Cia das Letras, 2012.

GIRARD, René. A Violência e o Sagrado. São Paulo: Paz e Terra/EdUNESP, 1990.

HUIZINGA, Johann. Homo Ludens. São Paulo: Perspectiva, $4^{a}$ ed., 1993.

GLIN, Tony. R.P.G. Rolyplaying Games - uma diversão perigosa que pode envolver demônios, assassinos $e$ todo o reino das trevas. Belo Horizonte: Editora Grei, 2005.

MARIZ, Cecília Loreto. O Demônio e os Pentecostais no Brasil. In: BIRMAN, Patrícia; NOVAES, Regina e CRESPO, Samira. (orgs.) O mal à brasileira. Rio de Janeiro: EdUERJ, 1997.

PINA CABRAL, João de. Semelhança e Verossimilhança: Horizontes da narrativa etnográfica. In: Mana, 9(1):109-122, 2003.

PIRES, Álvaro. A Racionalidade Penal Moderna, o Público e os Direitos Humanos. In: Novos Estudos CEBRAP. São Paulo, no. 68, março de 2004.

PLETSCH, Natalie Ribeiro. Formação da prova no jogo processual penal: o atuar dos sujeitos e a construção da sentença. São Paulo: IBCCRIM, 2007.

RICOEUR, Paul. Tempo e Narrativa. Volume 1. Campinas: Papirus, 1994.

RIFIOTIS, Theophilos. Nos Campos da Violência: Diferença e Positividade. In: Antropologia em Primeira Mão, Florianópolis, v. 19, p. 1-19, 1997.

Violência policial e imprensa: o caso da Favela Naval. In: São Paulo em Perspectiva. vol. 13, no. 4, São Paulo Oct./Dec., 1999.

SCHRITZMEYER, Ana Lúcia Pastore. Controlando o poder de matar: uma leitura antropológica do Tribunal do Júri - ritual lúdico e teatralizado. $284 \mathrm{f}$. Tese (Doutorado) Curso de Antropologia Social, USP, São Paulo, 2002.

TAUSSIG, Michael. O Diabo e o fetichismo da mercadoria na América do Sul. São Paulo: Editora Unesp, 2010.

Xamanismo, Colonialismo e o homem selvagem. Rio de Janeiro: Paz e Terra, 1993.

Mimesis and Alterity - a particular history of the senses. New York: Routledge, 1993.

TURNER, Victor W. Dramas, Campos e Metáforas - ação simbólica na sociedade humana. Niterói: Editora da Universidade Federal Fluminense, 2008.

From Ritual to Theatre. New York: PAJ Publications, 1982. 
288 | Ana Letícia de Fior

VASQUES, Rafael Carneiro. As potencialidades do RPG

(Role Playing Game) na Educação Escolar. Disserta-

çẫo (Mestrado). Curso de Educação, UNESP/Araraquara, 2008.

autora Ana Letícia de Fiori

Doutoranda em Antropologia Social / USP

Recebido em 25/11/2013

Aprovado para publicação em 16/12/2013 